\title{
XIX sajand - murranguaeg eesti folklooris ja alusterajaja folkloristikas
}

Avaldatud: 38. Kreutzwaldi päevad: Ettekannete teesid: 21. ja 22. detsembril 1994. a/ toim: Sirje Olesk. Tartu: Eesti Teaduste Akadeemia, Eesti Kirjandusmuuseum, 1994, lk 13-14

XIX sajand on eesti kultuuriloos murranguline aeg. Eriti avaldub see kahes aspektis, mis sisuliselt on ühe nähtuse erinevad küljed: ühelt poolt on tegemist pärimusliku rahvakultuuri kiire taandumise, kohati lausa hääbumisega; teiselt poolt rahvuskultuuri aluste rajamisega.

Koolivõrgu laienemine ja kirjaoskuse kasv, ajalehtede asutamine, tarbe- ja ilukirjanduse tekkimine on põhiliselt XIX sajandi nähtused. Rõhutaksin eriti seltside tekkimist ja seltsielu. Seltsid on tähtsad kaheti: põllumeesteseltsides (esimene oli Tartu PS 1870) aeti poliitikat (tõsi, esimene mekk saadi juba EKmS-is ja Aleksandrikooli komiteedes); laulu- ja mänguseltsides (Tartus Vanemuine, Tallinnas Estonia 1865) võeti kasutusele n.-ö. kaasaegne ajaviide: mitmehäälne laul, pillimuusika, näitemängud, tantsuõhtud. Kõik see tõrjus igapäevasest elust kõrvale vana, pärimusliku kultuuri.

Rahvalauludes toimunud murrangut on jälginud mitmed uurijad (T. Okkola, I. Rüütel, Ü. Tedre). Rahva proosaloomingu muutumisest on vähe kõneldud. Kui võrrelda vanu kogusid (ÕES, Rosenplänter, EKÜ) hilisematega, siis torkab silma muinasjuttude taandumine muistendite ja naljandite arvel (mõistagi võib see sõltuda kogumisele asetatud rõhust). Näiteks Kreutzwaldi ennemuistsete juttude kogus moodustavad paiklikud jutud ehk muistendid umbes kolmandiku. Hilisemates kogudes on suhe pigem vastupidine. Veel vähem on teateid lühivormide muutumisest. Võib oletada vanasõnade kasutatava hulga teatavat vähenemist, millega seostub mõningate kindlate tüüpide esilekerkimine koos improvisatsiooniliste, ühekordselt fikseeritud lausungite vohamisega. Võib arvata sedagi, et arvmõistatused ja keerdküsimused ilmusid mõistatuste repertuaari XIX sajandil.

Meie käsitlustes on koduvalt juhitud tähelepanu usuliikumistele kui rahvaluule kogumist oluliselt seganud tegurile. Vähe on pööratud tähelepanu kogujate ülestähendustes aeg-ajalt esinevatele märkustele, mille järgi noored - peremees, perenaine - põlastavad või lausa keelavad pöördumise vanade - pärimusliku 
kultuuri valdajate - poole (a la "Mis nad ka teavad!", "Mis sest vanast asjast pärida!” jm.). Talu peremehele, kes luges ajalehte, osales põllumeesteseltsis, lõi kaasa laulu-, mängu-, haridus- või karskusseltsis; kes võitles pastori ja paruni poolt kantud balti erikorra (hiljem aga venestumise) vastu - niisugusele talumehele pidi muistne pärimuslik kultuurilooming jäämagi võõraks. See oli tunnismärgiks ajast ja sõltuvussuhetest, millest ta kas püüdis vabaneda või oli alles äsja vabanenud.

Kui tärkav rahvuskultuur tõrjus vana pärimuslikku kultuuri, siis ometi tänu uuele kultuurisuundumusele tekkisid eeldused rahvaluule edukaks ja suureviisiliseks kogumiseks. Nimelt seltside (eelkõige EKmS), ajakirjanduse ja kirjanduse (eelkõige M. J. Eiseni väljaanded) kaudu selgitati rahvaluule olemust ja tähtsust ning tema kogumise vajadust. Ilmekaks näiteks on siin kaks arvu. Kui sajandi kolmandal veerandil EKmS-il oli (V. Mälgu järgi) 149 kaastöölist (ja 28 anonüümset saadetist, seega maksimaalselt 177 korrespondenti), siis J. Hurdal oli tema viimase XIX sajandil kirjutatud aruande järgi (125. aruanne 10. juulil 1897) 881 kaastöölist. Arvestades ligi kolmeaastast pausi ja 126. aruandes esinevat märkust "Vaheajal on järgmised suguvennad vanavara saatnud", võib kogujate arv ulatuda 892-ni. Seega on kogujate arv kasvanud - EKmS-i aegadega võrreldes - rohkem kui viiekordseks. Kui lisada siia veel M. J. Eiseni kaastöölised, kasvab kogujate arv veelgi. See olnuks võimatu, kui ei oleks olnud ajalehti ja nende lugejaid. 